\title{
Kajian Estetika Postmodern Terasering Sawah Di Desa Wisata Jatiluwih Sebagai Daya Tarik Wisata
}

\author{
Dewa Putu Oka Prasiasa ${ }^{1}$, Dewa Ayu Diyah Sri Widari ${ }^{2}$ \\ ${ }^{1}$ Prodi S1 Manajemen, STIMI Handayani, Denpasar \\ Jl. Tukad Banyusari No. 17B, Denpasar, Bali, Indonesia 80225 \\ ${ }^{2}$ Prodi D3 Perhotelan, Akademi Pariwisata Denpasar, Denpasar \\ Jl. Tukad Balian No. 15 Niti Mandala Renon, Denpasar, Bali, Indonesia 80226 \\ 1'dewaputuoka18@gmail.com
}

\begin{abstract}
Berkembangnya desa wisata dengan memanfaatkan terasering sawah sebagai daya tarik wisata, menimbulkan dampak berupa pergeseran nilai estetis, bentuk, fungsi, dan makna dari terasering sawah. Pergeseran nilai estetis, bentuk, fungsi, dan makna menjadi fokus dalam penelitian ini. Penelitian ini mempergunakan metode tinjauan pustaka berdasarkan analisis estetika postmodern. Penelitian ini menemukan dengan dijadikannya terasering sawah sebagai daya tarik wisata di Desa Wisata Jatiluwih, telah menimbulkan pergeseran pada nilai ekonomi, nilai hiburan,nilai estetis, dan nilai religius. Aspek bentuk, terjadi pergeseran akibat dipergunakannya bahanbahan yang berasal dari luar desa setempat sebagai pelengkap terasering sawah. Aspek fungsi, tidak terjadi pergeseran, karena terasering sawah tetap dipergunakan sebagai sarana menyalurkan air oleh subak. Aspek makna, dengan dijadikannya terasering sawah sebagai daya tarik wisata menimbulkan makna estetis berupa penyaluran rasa estetis petani pada saat membuat terasering sawah, makna lingkungan berupa pelestarian terasering sawah, serta makna budaya berupa berkembangnya budaya global sebagai akibat dijadikannya terasering sawah sebagai daya tarik wisata di desa wisata.
\end{abstract}

Kata kunci: estetis, bentuk, fungsi, makna, terasering, jatiluwih.

\section{Postmodern Aesthetic Study of Rice Terraces in JatiluwihTourism Village as a Tourist Attraction}

The development of tourism villages by utilizing rice terraces as a tourist attraction has resulted in a shift in the aesthetic value, form, function and meaning of rice terraces. The shifting of aesthetic values, forms, functions, and meanings is the focus of this research. This study used a literature review method based on postmodern aesthetic analysis. This study found that the use of rice terraces as a tourist attraction in Jatiluwih Tourism Village has led to a shift in economic values, entertainment values, aesthetic values, and religious values. In terms of form, there is a shift due to the use of materials from outside the local village as a complement to rice terraces. In terms of function, there is no shift, because the rice terraces are still used as a means of channeling water by the subaks. The aspect of meaning, by making rice terraces as a tourist attraction creates an aesthetic meaning in the form of channeling the aesthetic taste of farmers when making rice terraces, the environmental meaning in the form of preservation of rice terraces, and the cultural meaning in the form of the development of global culture as a result of making rice terraces as a tourist attraction in the tourism village.

Keywords: aesthetics, form, function, meaning, terraces, jatiluwih.

Proses Review : 1 - 30 Juni 2021, Dinyatakan Lolos: 27 Juli 2021 


\section{PENDAHULUAN}

Sebagai sebuah kompleksitas bisnis, dalam kepariwisataan terdapat berbagai fenomena yang merupakan hubungan timbal-balik dan interaksidi antara pemangku kepentingan. Para pemangku kepentingan tersebut oleh Perlas (2000) disebut sebagai threefolding yang terdiri dari pemerintah, dunia usaha pariwisata dan masyarakat sebagai penerima kehadiran wisatawan (host). Hubungan timbal balik serta interaksi di antara pemangku kepentingan terjadi untuk menciptakan daya tarik wisata dan juga sebagai upaya untuk menjamu kehadiran wisatawan dan pengunjung (visitor) didaya tarik wisata (Gartner, 1996:5-7). Dalam kaitan dengan threefolding, masyarakat disebut sebagai dimensi budaya, dunia usaha pariwisata disebut sebagai dimensi ekonomi serta pemerintah disebut sebagai dimensi politik.

Menurut Undang-Undang Nomor 10 Tahun 2009 tentang Kepariwisataan, yang dimaksud dengan daya tarik wisata adalah segala sesuatu yang memiliki keunikan, keindahan, dan nilai yang berupa keanekaragaman kekayaan alam, budaya, dan hasil karya buatan manusia yang menjadi sasaran atau tujuan kunjungan wisatawan. Dari definisi tersebut menyiratkan begitu luasnya ruang lingkup yang diberikan untuk daya tarik wisata, sehingga hal-hal atau sesuatu yang menarik bagi wisatawan itu lebih lanjut dikelompokkan menjadi tiga yaitu segala sesuatu yang berasal dari alam (natural resources), segala sesuatu yang berasal daribudaya (culture resources), dan segala sesuatu hasil karya manusia (man made resources).

Daya tarik wisata yang berasal dari alam, budaya dan hasil karya manusia tidak bisa dilepaskan dari keindahan, baik keindahan yang disediakan oleh alam maupun keindahan yang diciptakan oleh manusia sebagai sebuah produk seni dan budaya. Ini berarti, karena adanya keindahan itulah maka seseorang akan melakukan perjalanan wisata untuk melihat dan mengunjungi daya tarik wisata, selain adanya jaminan keamanan yang merupakan syarat utama dalam kepariwisataan. Dengan demikian, keindahan daya tarik wisata (termasuk produk seni dan budaya yang ada di dalamnya) merupakan faktor penarik (full factor) wisatawan mengunjungi daya tarik wisata.

Salah satu daya tarik wisata yang merupakan kombinasi antara alam dan hasil karya manusia yang mengandung nilai keindahan adalah terasering sawah. Dalam penelitian ini terasering sawah yang dijadikan objek kajian adalah terasering sawah yang terdapat di Desa Wisata Jatiluwih, Kabupaten Tabanan, Provinsi Bali. Terasering sawah di Desa Wisata Jatiluwih dijadikan objek kajian karena terasering sawah tersebut merupakan bagian dari Warisan Budaya Dunia yang diperoleh Bali dari UNESCO pada Juni 2012 dengan label Cultural Lanscape of Bali Province: the Subak System as a Manifestation of the Tri Hita Karana Philosophy (Lanskap Budaya Provinsi Bali: Sistem Subak sebagai Manifestasi Filosofi Tri Hita Karana). Penetapan Lanskap Budaya Provinsi Bali sebagai Warisan Budaya Dunia pada Sidang ke-36 Komite Warisan Dunia karena subak memiliki nilai luar biasa yang bersifat universal (outstanding universal velue) yang mencakup tiga hal yaitu pertama, memiliki keunikan atau pengakuan luar biasa terhadap tradisi budaya atau peradaban yang masih berlaku (unique testimonies to cultural traditions/ civilisations); kedua, merupakan contoh yang luar biasa tentang pemukiman tradisional manusia dan tata guna tanah (traditional human settlement, land use, or sea use); ketiga, peristiwa atau tradisi yang berlaku dengan gagasan atau dengan keyakinan yang memiliki nilai universal luar biasa dan secara langsung membentuk lanskap (association with events or living traditions).

Meskipun ditetapkan sebagai Warisan Budaya Dunia, sebagian besar masyarakat di Desa Wisata Jatiluwih tetap memilih bertani atau mempertahankan budaya agraris dengan sistem pertanian tradisional. Mareka tidak tertarik untuk masuk ke kancah industrialisasi termasuk industrialisasi dalam sistem pertanian mereka, padahal para petani di wilayah sekitarnya atau wilayah Catur Angga Batukaru sudah mulai masuk ke kancah pertanian modern yang ditandai dengan penggunaan mesin-mesin untuk pertanian. Mengacu pada Sairin (2002:172), kondisi tersebut merupakan pertentangan dari kondisi masyarakat Indonesia pada masa transisional, dengan ciri masyarakat transisional cenderung berpindah dari kehidupan agraris tradisional yang penuh nuansa spiritualistik dan majik menuju masyarakat industrial yang cenderung materialistik dan rasional. Kebertahanan masyarakat terhadap sistem pertanian tradisional ini bisa juga dilihat dari konteks perlindungan terhadap pekerja wanita di pedesaan, karena jika industrialisasi dibiarkan berkembang pada pertanian akan mengakibatkan menyusutnya lapangan pekerjaan bagi wanita di pedesaan (Sairin, 2002) atau juga bisa dilihat dari upaya memegang teguh prinsif safety first dan menolak introduksi teknologi baru dalam pertanian.

Berkembangnya Desa Wisata Jatiluwih dengan memanfaatkan label Warisan Budaya Dunia, telah menimbulkan dampak pada masyarakat desa yang berprofesi sebagai petani. Masyarakat desa dalam hal ini petani yang sawahnya memiliki terasering yang indah dan berada di lokasi Warisan Budaya Dunia, bisa mewujudkan keinginannya untuk menolak industrialisasi pertanian berupa penggunaan mesin-mesin dalam pengolahan pertanian. Masyarakat akan bisa terus bertani dengan sistem pertanian tradisional dan dapat mewariskan suatu bentuk sistem pengairan tradisional yang baik dan indah berwujud terasering kepada generasi mendatang. Pada sisi lain, masyarakat petani yang lokasi sawahnya berada di area Warisan Budaya Dunia, juga akan masuk ke dalam industrialisasi pariwisata. Kedua dampak terhadap masyarakat petani terjadi karena keindahan yang ada pada terasering sawah, artinya jika terasering sawah secara 
ketat dipertahankan sebagai Warisan Budaya Dunia, maka unsur keindahan tetap harus dijaga di samping authenticity, sedangkan jika masuk ke kancah industri pariwisata, maka unsur keindahan mutlak diperlukan dan dapat mengakibatkan terjadi komodifikasi.

Era postmodern merupakan era yang cenderung memiliki perbedaan tajam antara realitas dan fantasi (simulacra) sehingga menimbulkan keyakinan pada suatu realitas objektif. Postmodern umumnya tidak suka dengan penyeragaman, akan tetapi lebih senang menerima perbedaan. Postmodernis juga mengakui bahwa subjek dan rasionalitas itu tidak satu atau seragam. Selanjutnya menurut Mowforth and Maunt (2000:45) selain keindahan, dalam pariwisata postmodern juga ditampilkan daya tarik wisata seperti gambaran tentang kemiskinan, atau menurut Ali (2004:11), estetika tidak hanya menyelidiki yang indah, tetapi juga yang buruk. Kemiskinan berbeda dengan keindahan, menurut Purnawangsih dkk. (2020), keindahan adalah representasi dari nilai estetis.

Berdasarkan uraian tersebut, perlu mengkaji keindahan (estetis) dari terasering sawah Desa Wisata Jatiluwih sebagai daya tarik wisata dengan pendekatan postmodern. Kajian terhadap daya tarik wisata tersebut diperlukan karena selain terasering sawah di Desa Wisata Jatiluwih merupakan bagian dari Warisan Budaya Dunia, juga karena terdapat fenomena yang berkembang di masyarakat Desa Wisata Jatiluwih yaitu mempertahankan sistem pertanian tradisional. Fenomena ini merupakan sumbangsih budaya tradisional untuk memperkaya daya tarik wisata di Desa Wisata Jatiluwih.

\section{METODE PENELITIAN}

Kajian estetika terasering sawah di Desa Wisata Jatiluwih menggunakan metode tinjauan pustaka berdasarkan analisis estetika postmodern. Sebagai sebuah metodologi yang jarang diimplementasikan dalam suatu penelitian, menurut Snyder (2019), tinjauan pustaka dapat diperlakukan sebagai metodologi penelitian. Metode tinjauan pustaka juga dikenal sebagai metode literatur atau juga disebut sebagai Comprehensive Literature Review (Onwueg and Frels, 2016). Ini berarti metode tinjauan pustaka merupakan metodologi analisis teoretis yang mengkaji dan membahas materi secara teoretis dan deskriptif, dan dalam konteks tertentu dapat dilakukan perbandingan dengan sebuah konsep (Comerasamy, 2012).

\section{HASIL DAN PEMBAHASAN}

\section{Deskripsi Objek}

Desa Wisata Jatiluwih terletak pada ketinggian sekitar 700 meter di atas permukaan laut dan berlokasi lebih kurang 27 kilometer ke utara kota Tabanan. Jatiluwih merupakan salah satu daya tarik wisata di Kecamatan Penebel Kabupaten Tabanan dari dua puluh enam daya tarik wisata yang ditetapkan berdasarkan Surat Keputusan Bupati Tabanan Nomor 470 Tahun 1998, Surat Keputusan Bupati Tabanan Nomor 337 Tahun 2004 dan Surat Keputusan Bupati Tabanan Nomor 266 Tahun 2007. Keduapuluh enam daya tarik wisata yang ditetapkan berdasarkan ketiga Surat Keputusan Bupati Tabanan tersebut antara lain Ulun Danu, Kebun Raya Eka Karya, Bedugul, Yeh Panes dan Hutan Bambu Angseri, Taman Pujaan Bangsa Margarana, Alas Kedaton, Tanah Lot, Sanggar Tari Whratnala, Museum Subak, Pantai Yeh Gangga, Taman Kupu-Kupu Lestari, Areal Batukaru, Jatiluwih, Yeh Panes Belulang, Yeh Panes Penatahan, Pantai Pasut, Pantai Kelating, Puri Gede Kerambitan, Puri Anyar, Pantai Soka, Pantai Sureberata, Sarinbuana, Hutan Mekori, Air Terjun, Perkebunan Pujungan, Desa Wisata Pinge dan Bendungan Telaga Tunjung.

Desa Wisata Jatiluwih memiliki atraksi wisata yang sekaligus dapat diapresiasi oleh wisatawan. Atraksi wisata yang dapat disaksikan antara lain serangkaian potensi yang tersedia sepanjang tahun yaitu, alam pegunungan, terasering sawah, dan arsitektur tradisional rumah-rumah penduduk khususnya keberadaan lumbung padi (jineng) di areal pekarangan penduduk setempat. Wisatawan dapat berjalan-jalan melintasi pematang sawah dan menikmati pemandangan sawah, panorama sawah yang disertai aktivitas tradisional, seperti membajak, menyiapkan bibit, menanam, menuai, dan memasukkan padi ke lumbung. Khusus tentang atraksi wisata berupa aktivitas tradisional seperti membajak, menyiapkan bibit, menanam, menuai, dan memasukkan padi ke lumbung menurut Prasiasa dan Widari (2019), merupakan ikon Desa Wisata Jatiluwih, namun tidak bisa terselenggara sepanjang tahun karena proses penanaman padi tidak berlangsung sepanjang tahun.

Bagi wisatawan yang menyukai kegiatan alam terbuka (outdoor activity), apresiasi pada pegunungan, terasering persawahan, dan pedesaan tradisional dapat ditingkatkan ke dalam aktivitas trekking (penjelajahan). Dalam aktivitas ini diharapkan sebanyak mungkin unsur alam dapat dinikmati oleh wisatawan, misalnya sawah, sungai, suasana desa, jalan setapak, hutan, tanjakan, turunan, mata air, perkebunan, dan berbagai pemandangan untuk keperluan fotografi. Daya tarik wisata lain berupa upacara yang terkait dengan aktivitas pertanian, serta persiapan di balik upacara tersebut. Semua rangkaian upacara yang menyertai proses pengolahan sawah dari awal hingga panen di Desa Wisata Jatiluwih, dikenal dengan istilah pula pali metandur padi ring carik (Prasiasa dkk., 2019).Semua rangkaian upacara tersebut melibatkan unsur masyarakat termasuk subak. Wisatawan dapat menyaksikan kegiatan tersebut, sehingga secara tidak langsung dapat melihat budaya pertanian yang ada di masyarakat desa setempat.

Terkait dengan potensi kesenian, tarian joged bumbung dari Desa Jatiluwih sudah dikenal olehmasyarakat. Potensi tarian joged bumbung ini bisa dikaitkan dengan aktivitas 
Tabel 1. Potensi Kesenian Desa Wisata Jatiluwih

(Sumber: Hasil Penelitian)

\begin{tabular}{|c|c|c|c|c|c|c|}
\hline \multirow{2}{*}{ No } & \multirow{2}{*}{$\begin{array}{c}\text { Nama } \\
\text { Kesenian }\end{array}$} & \multicolumn{2}{|c|}{ Keberadaan } & \multicolumn{2}{|c|}{ Sifat } & \multirow[b]{2}{*}{ Profan } \\
\hline & & Eksis & Punah & Sakral & Semi Sakral & \\
\hline 1. & Gong & $\mathrm{X}$ & & & $\mathrm{X}$ & \\
\hline 2. & $\begin{array}{l}\text { Joged } \\
\text { Bumbung }\end{array}$ & $\mathrm{X}$ & & & & $\mathrm{X}$ \\
\hline 3. & $\begin{array}{l}\text { Wayang } \\
\text { Kulit }\end{array}$ & & $\mathrm{X}$ & & & $\mathrm{X}$ \\
\hline 4. & Pesantian & $\mathrm{X}$ & & & $\mathrm{X}$ & \\
\hline 5. & Gender & & $\mathrm{X}$ & & $\mathrm{X}$ & \\
\hline 6. & Arja & & $\mathrm{X}$ & & & $\mathrm{X}$ \\
\hline 7. & Janger & & $\mathrm{X}$ & & & $\mathrm{X}$ \\
\hline 8. & Bondres & & $\mathrm{X}$ & & & $\mathrm{X}$ \\
\hline 9. & Tupeng & & $\mathrm{X}$ & & & $\mathrm{X}$ \\
\hline 10. & Baris & & $\mathrm{X}$ & & $\mathrm{X}$ & \\
\hline 11. & Jauk & & $\mathrm{X}$ & & $\mathrm{X}$ & \\
\hline 12. & Legong & $\mathrm{X}$ & & $\mathrm{X}$ & & \\
\hline 13. & Pendet & $\mathrm{X}$ & & & $\mathrm{X}$ & \\
\hline 14. & $\begin{array}{l}\text { Baris } \\
\text { Memedi }\end{array}$ & $X$ & & $X$ & & \\
\hline
\end{tabular}

wisatawan selama berwisata di desa wisata, misalnya sebagai pengiring bagi wisatawan yang sedang menikmati makan malam. Selain potensi kesenian berupa joged bumbung, beberapa kesenian lainnya yang ada di Desa Wisata Jatiluwih dapat dilihat pada Tabel 1.

\section{Kekhususan Objek}

Sebagai sebuah desa tradisional, Desa Wisata Jatiluwih memiliki panorama yang sangat indah, berlokasi di kaki Gunung Batukaru, dengan ciri khasnya adalah terasering sawah. Pola hidup masyarakat yang bertempat tinggal di desa ini adalah bersifat agraris-religius, dan merupakan daya tarik bagi wisatawan yang membutuhkan apresiasi budaya. Jika dirinci, beberapa kekhususan Desa Wisata Jatiluwih sebagai destinasi pariwisata adalah adanya pola terasering yang memperindah pemandangan alam dan menjadi setting utama pemandangan setempat, di samping aktivitas ritual yang terkait dengan bercocok tanam padi. Terasering sawah yang ada dibuat secara simetris dengan garis serta lekukan yang sangat indah dengan latar belakang alam pedesaan dan pegunungan yang indah; jenis kesenian yang ada di desa setempat; penataan desa dan arsitektur tradisional Bali yang spesifik; dan kegiatan pertanian yang masih tradisional khas padi sawah diAsia Tenggara, dengan ciri antara bulan Oktober hingga Januari berlangsung aktivitas penyiapan lahan, bibit dan penanaman, sedangkan Mei hingga Juli diisi dengan kegiatan menuai dan penyimpanan ke lumbung padi. Adapun terasering sawah dan jineng sebagai tempat penyimpanan padi di Desa Wisata Jatiluwih seperti Gambar 1.

\section{Konteks Budaya}

Jika berbicara terasering sawah sebagai hasil karya manusia yang mempergunakan cipta, rasa, dan karsa, secara sederhana dapat dikatakan bahwa terasering sawah dapat dimasukkan sebagai produk budaya, karena terasering sawah tersebut dibuat di samping untuk memenuhi fungsi utamanya sebagai media pengaturan irigasi persawahan, juga dalam pengerjaannya mempergunakan rasa estetis, sekaligus pikiran estetis yang didasarkan padapengetahuan estetis yang dimiliki oleh seorang petani.

Dilihat dari unsur kebudayaan (Koentjaraningrat, 1997:2) yang terdiri dari sistem relegi dan upacara keagamaan, sistem dan organisasi kemasyarakatan, sistem pengetahuan, bahasa, kesenian, sistem mata pencaharian, dan sistem teknologi dan peralatan, maka dalam konteks yang lebih luas, terasering sawah sebagai komponen pendukung sistem pertanian khususnya dalam hal pengairan juga dapat masuk ke dalam unsur kebudayaan yaitu sistem pengetahuan dan sistem mata pencaharian. Sedangkan jika dikaitkan dengan wujud kebudayaan (Koentjaraningrat, 1997:5) yang terdiri dari wujud kebudayaan sebagai suatu kompleks dari ide-ide, gagasan, nilai-nilai, norma-norma, peraturan; wujud kebudayaan sebagai kompleks aktivitas kelakuan berpola dari manusia dalam masyarakat; dan wujud kebudayaan sebagai benda-benda hasil karya manusia, maka jika dikaitkan dengan daya tarik wisata, terasering sawah dapat dilihat sebagai produk hasil karya manusia yang mempergunakan pengetahuan serta memiliki nilai estetis, dan terasering sawah merupakan simbol dari perwujudan mata pencaharian masyarakat setempat. Ini 


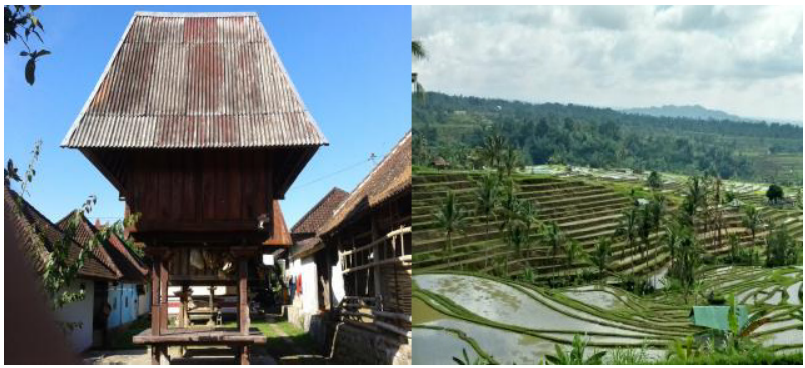

Gambar 1. Jineng dan Terasering Desa Wista Jatiluwih (Foto: Dokumentasi Pribadi)

berarti, terasering sawah merupakan produk budaya yang bernilai estetis, dan berarti pula dalam membicarakan budaya akan selalu terkait dengan pembicaraan tentang estetis. Terasering sawah dianggap sebagai produk budaya, karena kebudayaan adalah suatu realitas, suatu yang sudah diciptakan, sudah dihasilkan, sudah terbentuk atau sudah dilembagakan. Jika kebudayaan dilihat sebagai proses, maka proses itupun adalah suatu proses, sebagaimana yang sudah ada dan sudah berjalan. Kalaupun selama proses ada perubahan, maka perubahan yang dilihat adalah perubahan yang bersifat de facto, yaitu bagaimana perubahan itu berlangsung dalam kenyataannya, termasuk bentuk, fungsi serta substansi produk baru tersebut. Batasan ini dikembangkan oleh para ilmuwan sosial (Kleden, 1987:167-168). Jika dikaitkan dengan konteks terasering sawah, perubahan bentuk terasering dari sebuah sawah merupakan konsekuensi dari fungsi awal dari dibuatnya terasering, yaitu sebagai upaya memperlancar pengairan sawah. Kalaupun perubahan bentuk terasering itu memiliki nilai estetis, maka itu merupakan dampak ikutan.

Berbicara masalah budaya yang dikaitkan dengan estetis, sejalan dengan definisi budaya menurut Storey (2003:23 ), menyatakan bahwa budaya merupakan proses umum perkembangan intelektual, spiritual dan estetis. Lebih lanjut Storey menyatakan, bahwa budaya bisa merujuk kepada karya dan praktik-praktik intelektual, terutama aktivitas artistik. Jika dikaitkan dengan terasering sawah, maka terasering sawah tersebut diciptakan sebagai perkembangan dari pengetahuan petani akan sistem pengairan. Dalam proses penciptaan terasering sawah terdapat sentuhan artistik dari petani yang hasilnya berwujud terasering sawah yang berundak-undak dan berkelok-kelok secara simetris. Terasering sawah tersebut selain memiliki nilai keindahan, juga menjalankan fungsi utama yaitu untuk memperlancar aliran air dari satu petak sawah ke petak sawah berikutnya.

\section{Kajian Estetika}

Estetika adalah salah satu unsur yang penting dalam hidup manusia, karena ia menggerakkan manusia ke arah konstruktif dalam berbagai lapangan hidup, antara lain kepada rasa jengah yang berlandaskan rajasika dan satwika (Mantra, 1996:12). Dengan adanya rasa jengah yang dilandasi rajasika dan satwika itu, manusia akan terpacu untuk berbuat dan menghasilkan sesuatu yang bernilai, baik bernilai guna maupun bernilai keindahan. Sesuatu yang dihasilkan oleh manusia dalam konteks rasa jengah itu, tentu dari sisi produk atau bendanya akan terkait dengan bentuk, fungsi dan makna.

Dalam bentuk, fungsi dan makna, terdapat satu hal yang sangat fundamental bahwa bentuk, fungsi dan makna adalah sebuah pendekatan (Ratna, 2003:112). Pendekatan bentuk, fungsi dan makna jelas merupakan pemahaman total atas objek yang dikaji. Pendekatan ini sesuai dengan metode kualitatif dengan ciri adanya data yang bersifat alamiah, serta objek penelitian tidak terpisah dengan latar belakang sosial yang menghasilkannya. Beberapa hal yang perlu mendapat perhatian dengan mempergunakan pendekatan bentuk, fungsi dan makna adalah harus ada pemahaman tentang mana yang termasuk bentuk, fungsi dan makna; penelitian difokuskan pada makna, bukan bentuk dan fungsi; dan teori yang dipergunakan harus dapat menyatukan ketiga komponen tersebut menjadi satu kesatuan. Menurut Mudana (2003:88), pada umumnya bentuk terdiri atas deskripsi unsur-unsur formal, infrastruktur material dan sistem kebudayaan fisik. Fungsi terkait dengan struktur sosial dan sistem sosial, sedangkan makna terkait dengan suprastruktur ideologis dan sistem budaya.

Selain pendekatan bentuk, fungsi, dan makna, dalam estetika dikenal dua pendekatan (Sutrisno dan Verhaak, 1993:81), yaitu langsung meneliti keindahan itu dalam objek-objek dan benda-benda atau alam indah, serta karya seni; dan menyoroti situasi kontemplasi rasa indah yang sedang dialami oleh subjek (pengalaman keindahan dalam diri orangnya). Dalam kerangka pemikiran postmodern, pendekatan yang sering dipakai adalah pendekatan yang kedua yang terkait dengan pengalaman keindahan. Hal ini sejalan dengan credo dari Clive Bell bahwa estetika mesti berangkat dari pengalaman pribadi yang berupa rasa khusus atau istimewa (Sutrisno dan Verhaak, 1993:81). Dalam kaitan dengan kontemplasi subjek tersebut, rasa (teste) subjek akan objek yang diapresiasi juga akan menentukan penilaian estetisnya, sehingga teori selera (taste) dapat dipergunakan sebagai pisau analisis akan pengalaman keindahan.

Penilaian manusia terhadap keindahan (estetis) dari sebuah bentuk produk budaya, menurut Ratna(2007:199), bahwa keindahan adalah nilai. Sifatnya ideal, abstrak, tidak dapat disentuh dengan indra. Sedangkan menurut Frondisi (2001:8), ada tiga kualitas nilai, yaitu: kualitas primer, kualitas dasar, yang tanpa kehadirannya objek tidak dapat menjadi ada; kualitas sekunder, kualitas yang dapat ditangkap oleh indra, kualitas yang harus menghadirkan subjek untuk memahaminya, seperti rasa, warna dan bau; dan kualitas tersier yaitu nilai itu sendiri. Gie (1976:145146), membedakan delapan macam nilai manusiawi yaitu nilai ekonomis (mengandung aspek-aspek harga pasar); 
nilai jasmani (mengandung aspek-aspek kesehatan badan); nilai hiburan (mengandung aspek-aspek permainan dan waktu luang); nilai sosial (mengandung aspek-aspek hubungan antar manusia); nilai watak (mengandung aspek-aspek kepribadian); nilai estetis (mengandung aspek-aspek keindahan); nilai intelektual (mengandung aspek- aspek ilmu pengetahuan); dan nilai religius (mengandung aspek-aspek ilahiah). Berdasarkan analisis estetis terhadap terasering sawah Desa Wisata Jatiluwih, dalam penelitian ini nilai estetis mengacu pada kualitas tersier dengan melihat penerapan delapan macam nilai manusiawi menurut Gie (1976).

\section{Analisis Bentuk, Fungsi dan Makna Terasering Sawah Desa Wisata Jatiluwih}

Terasering sawah di Desa Wisata Jatiluwih, dengan mempergunakan analisis bentuk, fungsi dan makna, dapat diuraikan sebagai berikut.

\section{Bentuk}

Menurut Winansih (2020), perwujudan estetika dalam kaitan keindahan sebagai nilai intrinsik (sifat baik suatu benda/obyek), dinyatakan dengan prinsip, kaidahkaidah keselarasan, keseimbangan dan lainnya. Untuk mewujudkan ini digunakan unsur-unsur garis, bentuk, totalitas, warna, tekstur, struktur masa dan ruang.

Dalam kaitan keindahan sebagai nilai intrinsik, terasering sawah di Desa Wisata Jatiluwih secara fisik berbentuk simetris (lebarnya hampir sama, tingginya hampir sama, bentuknya hampir sama dan dengan garis lekukan atau kelokan yang hampir sama) dan dapat digolongkan menganut collective style. Keindahan sebagai nilai intrinsik inilah akan dikonsumsi oleh pengunjung atau wisatawandengan cara masuk ke areal persawahan melalui terasering sawah. Dalam kaitan estetika postmodern, terasering sawah yang dibuat serba seragam atau menganut collective style bertentangandengan estetika postmodern. Postmodern lebih menyukai ketidakteraturan.

Menurut Prayitno et.al (2021), perubahan tanah pertanian menjadi tempat berdiam orang-orang akan menyebabkan penurunan kualitas lingkungan. Terkait dengan Prayitno et.al (2021), maka terasering sawah perlu dijaga kualitas dan kelestariannya. Meskipun terasering sawah sebagai daya tarik wisata, maka terasering sawah tidak dapat dijadikan tempat untuk semua pengunjung atau wisatawan jika ingin menikmati keindahan areal persawahan. Hal ini untuk menjaga agar terasering sawah selain sebagai daya tarik wisata, dapat terus berfungsi sebagai pengatur aliran air di sawah. Untuk itulah, menurut Kamurahan dkk. (2014), untuk tetap menjaga kualitas estetika, pembuatan terasering sawah perlu memperhatikan keterpaduan (unity), keseimbangan (balance), proporsi (proportion), skala (scale), dan irama (rhytm).

\section{Fungsi}

Fungsi awal terasering sawah di Desa Wisata Jatiluwih adalah dipergunakan oleh petani untuk mengatur sistem pengairan sawah, sehingga semua sawah (meskipun ada di lokasi terbawah) dapat terjangkau oleh air. Seiring dengan perkembangan daya tarik wisata, terasering sawah merupakan sebuah karya yang mengandung unsur keindahan, namun tetap berfungsi mengatur sistem pengairan sawah. Hal ini sejalan dengan Prayatna dkk. (2021), bahwa sebuah karya seni diciptakan tidak hanya memikirkan segi estetisnya saja melainkan juga memiliki fungsi yang melekat pada karya seni tersebut, dalam hal ini terasering sawah sebagai karya seni.

\section{Makna}

Berdasarkan konvensi sosial yang telah terbangun, makna merupakan tanda. Tanda memiliki arti (significant) dalam kaitannya dengan pembaca dan pembaca menghubungkan tanda dengan apa yang ditandakan (signifier). Menurut Permatasari (2018) pada penelitian estetika, makna timbul sebagai akibat hubungan intepretasi sebelum dan setelah mengamati objek penelitian. Makna yang muncul dari keberadaan terasering sawah adalah: makna estetis, merupakan cerminan estetis dari petani di Desa Wisata Jatiluwih yang berwujud keberadaan terasering dan tampil sangat simetris hampir pada semua aspek dari terasering sawah tersebut; makna kesadaran kolektif, yang tercermin melalui kegiatan gotong royong di antara pemilik sawah dalam membuat terasering sawah dan juga mengarah kepada budaya kolektif; makna persatuan dan kesatuan, merupakan cerminan persatuan dan kerjasama serta senasib sepenanggungan di antara para petani di Desa Wisata Jatiluwih, yangtercermin dalam pembagian air di antara petani pemilik sawah di teben (hulu) dan di luwan (hilir); makna kepribadian dari petani pembuat dan pemelihara terasering, dapat dilihat dari kerapihan dan kebersihan terasering sawah; makna tri hita karana, para petani yang membuat terasering sawahtersebut, khususnya yang terkait dengan hubungan yang selaras antara manusia dengan lingkungannya (palemahan), artinya petani dalam membuat terasering harus mengikuti lanskap alam dan tidak bisa memaksakan bentuk terasering seperti apa yang diinginkan oleh petani; makna etos kerja, adanya kinerja yang tinggi dari petani, karena dengan pengetahuan yang dimilikinya (meskipun tradisional) berusaha berkarya untuk menghasilkan yang terbaik dalam upaya menjaga produksi pertanian; makna local culture, terasering sawah merupakan upaya menjaga kebertahanan budaya lokal khususnya yang terkait dengan sistem mata pencaharian di bidang pertanian.

Setelah terasering sawah di Desa Wisata Jatiluwih dijadikan daya tarik wisata, dari pendekatan bentuk sudah mengalami perubahan (dilihat dari beberapa komponen terasering), seperti jembatan kecil dan pendek (di Bali 
Tabel 2. Pergeseran Bentuk, Fungsi dan MaknaTerasering Sawah Desa Wisata Jatiluwih

(Sumber: Hasil Penelitian)

\begin{tabular}{|c|c|c|}
\hline Pendekatan & Sebelum menjadi Daya Tarik Wisata & $\begin{array}{l}\text { Setelah menjadiDaya Tarik } \\
\text { Wisata }\end{array}$ \\
\hline Bentuk & $\begin{array}{l}\text { Bentuk simetris, mencerminkan } \\
\text { collective style, mempergunakan } \\
\text { bahan-bahan lokal }\end{array}$ & $\begin{array}{l}\text { Bentuk tetap simetris, namun pada beberapa komponen } \\
\text { mempergunakan bahan non lokal danada sentuhan } \\
\text { teknologi modern }\end{array}$ \\
\hline Fungsi & $\begin{array}{l}\text { Sebagai pengatursistem pengairan } \\
\text { sawah }\end{array}$ & $\begin{array}{l}\text { Sebagai pengatur sistem pengairan sawah serta daya tarik } \\
\text { wisata di desawisata }\end{array}$ \\
\hline Makna & $\begin{array}{l}\text { 1. Makna estetis } \\
\text { 2. Makna kesadarankolektif } \\
\text { 3. Makna persatuandan kesatuan } \\
\text { 4. Makna ekspresikepribadian } \\
\text { 5. Makna tri hitakarana } \\
\text { 6. Makna etos kerjaMakna local } \\
\text { culture }\end{array}$ & $\begin{array}{l}\text { 1. Cerminan estetis semakin tinggi, karena ada upaya } \\
\text { komersialisasi } \\
\text { 2. Lingkungan diperkosa, semata-mata untuk emenuhi } \\
\text { kebutuhan wisatawan } \\
\text { 3. Ada pengaruh budaya global }\end{array}$ \\
\hline
\end{tabular}

Tabel 3. Perbandingan Nilai Estetis Terasering Sawah Desa Wisata Jatiluwih Sebelum dan Sesudah dijadikan Daya Tarik Wisata (Sumber: Hasil Penelitian)

\begin{tabular}{|c|c|c|c|}
\hline No. & Nilai MenurutGie & Sebelum & Setelah \\
\hline 1. & $\begin{array}{l}\text { Nilai Ekonomi } \\
\text { (adanya aspekharga pasar) }\end{array}$ & Tidak Ada & $\begin{array}{l}\text { Ada (dalam bentuk postcard } \\
\text { dan foto digital) }\end{array}$ \\
\hline 2. & $\begin{array}{l}\text { Nilai Jasmani(adanya aspek } \\
\text { kesehatan badan) }\end{array}$ & Tidak Ada & Tidak Ada \\
\hline 3. & $\begin{array}{l}\text { Nilai Hiburan (adanya aspek } \\
\text { permintaan danwaktu luang) }\end{array}$ & Tidak Ada & $\begin{array}{l}\text { Ada (dikemasdalam bentuk } \\
\text { package tour menikmati } \\
\text { keindahan terasering } \\
\text { sawah) }\end{array}$ \\
\hline 4. & $\begin{array}{l}\text { Nilai Sosial (adanya aspek } \\
\text { hubungan antarmanusia) }\end{array}$ & Tidak Ada & Tidak Ada \\
\hline 5. & $\begin{array}{l}\text { Nilai Watak (adanya aspek } \\
\text { kepribadian) }\end{array}$ & Tidak Ada & Tidak Ada \\
\hline 6. & $\begin{array}{l}\text { Nilai Estetis (adanya aspek } \\
\text { keindahan) }\end{array}$ & Tidak Ada & $\begin{array}{l}\text { Ada (tergantungpada persepsi } \\
\text { dan motivasiwisatawan) }\end{array}$ \\
\hline 7. & $\begin{array}{l}\text { Nilai Intelektual (adanya aspek } \\
\text { pengetahuan) }\end{array}$ & Tidak Ada & Tidak Ada \\
\hline 8. & Nilai Religius (adnya aspek ilahiah) & $\begin{array}{l}\text { Ada (dilakukan oleh } \\
\text { petani terkait proses } \\
\text { dan upacara yang } \\
\text { menyertai dalam } \\
\text { pengolahan sawah) }\end{array}$ & $\begin{array}{l}\text { Ada (dilakukan oleh petani, } \\
\text { dan proses serta upacara yang } \\
\text { menyertai dalam pengolahan } \\
\text { sawah menjadi salah satu daya } \\
\text { tarik wisata di desa wisata) }\end{array}$ \\
\hline
\end{tabular}


dikenal dengan istilah titi), yang menghubungkan antar parit (pundukan) dan dipisahkan oleh selokan atau sungai kecil, dahulu dibuat dari kayu yang berasal dari pohonpohon setempat. Sekarang dengan masuknya pariwisata, dengan alasan menjaga keamanan wisatawan selama berwisata ke terasering sawah, titi yang menghubungkan antar pundukan itu dibuat dari beton. Dari pendekatan fungsi, sampai saat ini belum mengalami perubahan, sedangkan dilihat dari pendekatan makna sudah ada pergeseran. Adapun pergeseran itu dapat digambarkan seperti Tabel 2.

\section{Analisis Nilai Estetis Terasering Sawah Desa Wisata Jatiluwih}

Menurut Ratna (2007:199) keindahan adalah nilai. Dengan mengacu pada nilai estetis yang dikemukakan oleh Gie (1976), daya tarik wisata berupa terasering sawah di Desa Wisata Jatiluwih berdasarkan analisis nilai estetis, akan dikemukakan analisis terhadap kedelapan nilai pada terasering sawah tersebut, baik sebelum maupun setelah dijadikan daya tarik wisata. Adapun perbandingan nilai estetisnya seperti Tabel 3.

Tabel 3 memperlihatkan bahwa terasering sawah di Desa Wisata Jatiluwih semula dibuat dengan fungsi untuk sistem pengairan sawah, sehingga nilai estetis tidak ada. Terasering dibuat semata-mata agar air dapat dengan lancar mengalir dari sawah yang ada di permukaan tinggi ke sawah yang ada di bawahnya. Kalaupun terasering sawah dibuat berkelok-kelok, itu karena mengikuti lanskap tanah. Terasering juga dibuat lurus, namun tetap berundakundak. Nilai ekonomis dan nilai hiburan tidak tampil, dan dalam proses pembuatannya disertai dengan ritual. Namun setelah terasering tersebut dijadikan daya tarik wisata, terdapat beberapa nilai yang porsinya semakin menonjol, seperti nilai ekonomi, nilai hiburan, nilai estetis dan nilai religius. Munculnya nilai ekonomi pada terasering sawah, setelah dijadikan daya tarik wisata sejalan dengan Putra dkk. (2017), yang menyatakan makna ekonomi timbul dapat dilihat dari tujuan penciptaannya dengan harapan menarik calon klien (dalam hal ini pengunjung atau wisatawan). Sedangkan menurut Mumcu dan Kimzan (2015), nilai ekonomi yang ditimbulkan oleh karya estetika memiliki hubungan negatif dengan tampilan visualnya.

Sementara itu nilai watak semakin menurun, hal ini antara lain karena adanya perubahan pada komponen-komponen dari terasering. Seperti jembatan titi yang menghubungkan antara satu pundukan ke pundukan yang lain, yang dulu dibuat dari kayu seadanya, setelah dijadikan daya tarik wisata, titi tersebut diganti dengan jembatan dari beton, semata-mata karena alasan keamanan untuk wisatawan.

Terkait dengan kebudayaan yang menyimpulkan bahwa terasering sawah sebagai sebuah produk budaya, maka terasering sawah di Desa Wisata Jatiluwih belum mengalami art by metamorphosis, karena terasering tersebut, meskipun sudah menjadi daya tarik wisata, namun masih tetap berfungsi untuk memperlancar pengairan sawah. Terasering sawah akan berperan sebagai art by metamorphosis manakala terasering sawah tersebut sudah tidak lagi berfungsi mengalirkan air, dan hanya dijadikan pajangan serta ditonton keindahannya (baik lekukan teraseringnya maupun kesimetrisan undak-undaknya yang merupakan cerminan collective style). Dengan demikian, pendekatan fungsi menjadi kunci dari terasering sawah di Desa Wisata Jatiluwih, apakah dapat digolongkan art by metamorphosis atau tidak.

Selain adanya terasering sawah, dalam rangka memacu perkembangan pariwisata di Desa Wisata Jatiluwih, Universitas Gadjah Mada pada 1992 merekomendasikan untuk menjadikan desa ini sebagai Desa Wisata Terpadu (DWT). Untuk mendukung rekomendasi tersebut, pemerintah melalui Kanwil X Parpostel Bali telah membangun sebuah rumah tradisional yang bernuansa arsitektur Bali sebagai sebuah rumah contoh. Dalam perkembangannya, rumah contoh tersebut tidak berfungsi sebagaimana yang diharapkan. Akibatnya, rumah contoh tersebut menjadi terbengkelai (neglacted arts). Penyebabnya adalah rumah contoh tersebut letaknya tidak strategis yaitu tidak dekat dengan terasering sawah di Desa Wisata Jatiluwih.

Dengan dijadikannya terasering sawah Desa Wisata Jatiluwih sebagai bagian dari Warisan Budaya Dunia, hal ini sejalan dengan keinginan masyarakat untuk mempertahankan aktivitas pertanian. Namun demikian, dalam kaitan pelestarian Warisan Budaya Dunia, perlu dilakukan konservasi terhadap terasering tersebut. Dalam kaitan konservasi inilah Boniface (1999: 34), menyatakan bahwa kepariwisataan menyediakan konservasi dengan pembenaran secara ekonomi, kepariwisataan adalah satu cara untuk menunjang pembangunan konservasi, dan kepariwisataan dapat membawa sumber-sumber daya untuk konservasi. Hal ini menyiratkan bahwa dijadikannya terasering sawah sebagai daya tarik wisata yang berada di areal Warisan Budaya Dunia harus memerhatikan dua hal yang paling esensial, yaitu pembangunan dan pelestarian. Menurut Farid (2021), antara pembangunan dan pelestarian tidak boleh dilakukan dikotomi, melainkan keduanya harus berjalan berdampingan secara harmonis dan saling memperkuat.

Mengacu pada pernyataan Direktur Komisi Pedesaan Inggris, jika dikaitkan dengan terasering sawah di Desa Wisata Jatiluwih sebagai Warisan Budaya Dunia dan daya tarik wisata, terlihat bahwa pariwisata akan mampu menunjang secara ekonomi untuk membiayai konservasi terasering sawah Desa Wisata Jatiluwih, melalui pendapatan yang diperoleh dari kunjungan wisatawan. Namun demikian, patut dicatat bahwa pariwisata juga memiliki sisi destruktif(merusak), jika jumlah dan aktivitas wisatawan di Warisan Budaya Dunia yang dijadikan daya tarik wisata tidak dikendalikan. Hal ini juga pernah 
dikemukakan oleh UNESCO bahwa antara 1972 sampai 1980, masyarakat seluas- luasnya dapat mengunjungi setiap situs-situs warisan dunia. Akibatnya, banyak di antara situs- situs warisan dunia itu tidak mampu menahan tekanan (Boniface, 1999:34). Apa yang dikemukakan oleh UNESCO tersebut sebenarnya mengarah kepada daya tampung (carryingcapacity).

Dengan demikian, agar masyarakat Desa Wisata Jatiluwih tetap dapat hidup bertani, terasering sawahnya dapat menjadi bagian dari Warisan Budaya Dunia, dan tetap dapat menikmati hasil dari pariwisata tanpa komodifikasi yang berlebihan, maka pengembangan Desa Wisata Jatiluwih perlu dilakukan secara terpadu dengan pertanian serta melibatkan seluruh stakeholder. Pelibatan seluruh stakeholders akan sangat membantu pelestarian terasering sawah. Selain itu keterlibatan masyarakat lokal dalam pengembangan desa wisata menurut Prasiasa (2012), harus terbebas dari hegemoni. Tujuannya adalah untuk mempercepat keterpaduan pertanian dengan desa wisata dalam konsep Desa Wisata Terpadu. Implementasi konsep Desa Wisata Terpadu (DWT) menjadi penting karena DWT akan lebih mengutamakan wisatawan individual (kalaupun group dalam jumlah terbatas, dan bukan mass tourism), sehingga carrying capacity dapat terjaga; DWT akan mencegah komodifikasi yang berlebihan, karena DWT akan lebih banyak memasarkan produk lokal/desa setempat; aktivitas pertanian tradisional (seperti membajak dengan sapi pakai tenggala, meratakan tanah bajakan dengan lampit, metekap, memanen padi oleh para wanita desa dengan ketam atau anggapan) akan dapat berjalan seiring dengan aktivitas tersebut dijadikan daya tarik wisata; secara langsung dan tidak langsung DWT akan membuka lapangan kerja di desa sehingga mencegah alih fungsi pertanianmenjadi tempat industri berskala besar.

\section{SIMPULAN}

Dengan dijadikannya terasering sawah Desa Wisata Jatiluwih sebagai bagian dari Warisan Budaya Dunia (World Culture Heritage), mampu memertahankan budaya agraris dengan sistem pertanian tradisional. Dari konteks budaya melalui pendekatan bentuk, terasering sawah merupakan cerminan produk budaya khususnya dari sistem mata pencaharian yang bernilai estetis tinggi dan menganut collective style, sehingga dapat menjadi daya tarik utama bagi wisatawan dan tidak sejalan dengan estetika postmodern. Berdasarkan hasil analisis dengan pendekatan fungsi, tidak terjadi perubahan sebelum dan sesudah terasering sawah Desa Wisata Jatiluwih dijadikan daya tarik wisata. Sedangkan berdasarkan pendekatan makna, telah terjadi pergeseran yaitu sebelum dijadikan daya tarik wisata, makna terasering sawah di Desa Wisata Jatiluwih adalah cerminan estetis, adanya kesadaran kolektif, adanya persatuan dan kesatuan, cerminan kepribadian, pemahaman terhadap tri hita karana, cerminan etos kerja dan local culture. Setelah dijadikan daya tarik wisata maknanya adalah cerminan estetis semakin tinggi, adanyapemerkosaan terhadap lingkungan, dan hadirnya pengaruh budaya global yang dibawa oleh industri pariwisata.

Jika dilihat dari nilai estetis menurut Gie (1976), setelah terasering sawah dijadikan daya tarik wisata maka nilai ekonomi semakin berkembang dan menjadi dominan, komodifikasi yang berlebihan terhadap terasering sawah antara lain dengan memanfaatkan terasering sawah sebagai pusat aktivitas dan hiburan bagi wisatawan selama berwisata, interaksi masyarakat Desa Wisata Jatiluwih akan bertambah terutama secara nasional dan internasional, aspek kepribadian petani dan masyarakat pada terasering akan semakin memudar hanya karena usaha membuat produk yang customeroriented, eksploitasi yang berlebihan terhadap terasering sawah dan berdampak kepada tampilan estetisnya, dan semakin memudarnya nilai-nilai religius pada aktivitas yang dilaksanakan di terasering sawah. Terasering sawah di Desa Wisata Jatiluwih sebagai produk budaya belum mengalami art by metamorphosis, karena terasering sawah tersebut masih berfungsi untuk sarana pengairan sawah meskipun sebagai bagian dari Warisan Budaya Dunia dan sebagai daya tarik wisata.

\section{DAFTAR RUJUKAN}

\author{
Ali, M. 2004. Estetika Sebuah Pengantar Filsafat \\ Keindahan. Tangerang: Sanggar Luxor
}

Boniface, P. 1999. Mengelola Wisata Budaya Bermutu. Jakarta: Bagian Proyek Pengembangan Literatur Pariwisata Comerasamy, H. 2012. Literature based Research
Methodology. UK

Farid, H. 2021. Pengelolaan Warisan Dunia di Indonesia. Materi Webinar Pengelolaan Warisan Dunia di Indonesia tanggal 28 April 2021 dalam rangka memperingati Hari Warisan Dunia

Frondisi, R. 2001. Pengantar Filsafat Keindahan. Yogyakarta: Pustaka Pelajar

Gie, T.L. 1976. Garis Besar Estetik (FilsafatKeindahan). Yogyakarta: Karya

Gartner, W.C. 1996. Tourism Development: Principles, Processes, and Policies. USA: Thomson Publishing Company 
Kamurahan, S.R., Waani, J.O., Rogi, O.H.A. 2014. Studi Persepsi Masyarakat Terhadap Estetika Desain Fasade Bangunan Dengan Pendekatan Teori Subyektif Studi Kasus di Koridor Boulevard on Business (BoB) Jalan Piere Tendean Manado. Jurnal Media Matrasain, 11(2), $68-82$

Koentjaraningrat. 1977. Kebudayaan, Mentalitas dan Pembangunan. Jakarta: PT. Gramedia Pustaka Utama

Kleden, I. 1987. Sikap Ilmiah dan Kritik Kebudayaan. Jakarta: LP3ES

Mantra, I.B. 1996. Landasan Kebudayaan Bali. Denpasar: Upada Sastra

Mowforth, M., Maunt, I. 2000. Pariwisata dan Yang Berkelanjutan: Pariwisata Baru Dunia Ketiga. Jakarta: Bagian Proyek Pengembangan Literatur Pariwisata

Mudana, I G. 2003. Dari Filsafat Ilmu ke Bentuk, Fungsi, dan Makna. Dalam (ed) Pemahaman Budaya Di Tengah Perubahan. Denpasar: Program Studi S2 dan S3 Kajian Budaya

Mumcu, Y., Kimzan, H.S. 2015. The Effect of Visual Product Aesthetics on Consumers' Price Sensitivity. Procedia Economics and Finance, 26(2015), 528-534

Onwueg, A. J., \& Frels, R. 2016. Methodology of the Literature Review. In Seven Steps to a Comprehensive Literature Review; A Multimodal \& Cultural Approach. London: Sage Publication Ltd

Perlas, N. 2000. Shapping Globalization Civil Society, Cultural Power and Threefolding. New York: CADI and Global Network for Social Threefolding

Permatasari, R.P. 2018. Aesthetic research of the building heritage Toko Merah Roland Barthes semiotic approach. IOP Conf. Series: Materials Science and Engineering, 453, 1-13 doi:10.1088/1757-899X/453/1/012070

Purnawangsih, A., Margana., Sulistyo, E.T. 2020. Nilai Estetis Penampilan Busana Pengantin GayaSolo Basahan di Surakarta Hadiningrat. MUDRA Jurnal Seni Budaya, 35(2), 164-171

Putra, G.B.S., Artayasa, I N., Swandi, I W. 2017. Kajian Konsep, Estetik, dan Makna Pada Ilustrasi Rangda Karya Monez. Jurnal Prabangkara, 21(2), 68-79

Prasiasa, D.P.O., Widari, D.A.D.S. 2019. Traditional Agricultural Systems as Tourism Icon inJatiluwih Tourism Village, Tabanan Regency, Bali Province. Journal of Asian Development, 5(2), 89- 100
Prasiasa, D.P.O., Harwathy, T.I.S., Swaputra, I.B., Ratini, P.M. 2019. Pula Pali Metandur Padi Bali Ring Carik: Tourism Icons and Revitalizing Traditional Agricultural Systems in Jatiluwih Tourism Village, Tabanan Regency. The $9^{\text {th }}$ International Conference Rural Research and Planning, 347-356

Prasiasa, D.P.O. 2012. Hegemoni Pengembangan Pariwisata dan Keterlibatan Masyarakat di Desa Wisara. MUDRA Jurnal Seni dan Budaya, 27(1), 62-77

Dedy Prayatna, I. W., Santosa, H., \& Ratna Cora, T. I. (2021). Perkembangan Fungsi dan Makna Kain Tenun Gotya dalam Industri Fashion. Mudra Jurnal Seni Budaya, 36(1), 106-114. https://doi.org/10.31091/mudra. v36i1.1101

Prayitno, G., Rukmi, W. I. \& Ashari, M. I. 2021. Assessing the social factors of place dependencewith changes in land use in sustainable agriculture: Case of Pandaan District, Pasuruan Regency, Indonesia. Journal of Socioeconomics andDevelopment, $4(1), \quad 8-20$.

https://doi.org/10.31328/jsed.v4i1.1720

Ratna, N.K. 2003. Konsep dan Aplikasi Bentuk, Fungsi, dan Makna. Dalam (ed) Pemahaman Budaya di Tengah Perubahan. Denpasar: Program Studi S2 dan S3 Kajian Budaya

Ratna, N.K. 2007. Estetika Sastra dan Budaya. Yogyakarta: Pustaka Pelajar

Sairin, S. 2002. Perubahan Sosial Masyarakat Indonesia Perspektif Antropologi. Yogyakarta: Pustaka Pelajar

Sutrisno, M., Verhaak, C. 1993. Estetika Filsafat Keindahan. Yogyakarta: Kanisius

Snyder, H. 2019. Literature review as a research methodology: An overview and guidelines. Journal of Business Research, 104, 333-339

Storey, J. 2003. Teori Budaya dan Budaya Pop,Memetakan Lanskap Konseptual Cultural Studies. Yogyakarta: Penerbit Qalam

Winansih, E. 2010. Estetika Simbolis - Sensori Pada Ruang Publik Di Alun-alun Malang. Jurnal Local Wisdom, 2(3), 20-28

\section{Artikel Surat Kabar}

Bali Post 4 September 2006 berjudul Jati Luwih Menuju World Culture Heritage 


\section{Peraturan Perundang-Undangan}

Surat Keputusan Bupati Tabanan Nomor 470 Tahun 1998 tentang Penetapan Daya Tarik Wisata

Surat Keputusan Bupati Tabanan Nomor 337 Tahun 2004 tentang Penetapan Desa Adat Pinge, Kecamatan Marga menjadi Desa Wisata

Surat Keputusan Bupati Tabanan Nomor 266 Tahun 2007 tentang Penetapan Bendungan Telaga Tunjung, Desa Timpag, Kecamatan Kerambitan sebagai Daya Tarik Wisata

Undang-Undang Nomor 10 Tahun 2009 Tentang Kepariwisataan 